Article

\title{
Dynamic Coordination of Internal Displacement: Return and Integration Cases in Ukraine and Georgia
}

\author{
Oleg Bazaluk ${ }^{1, *(1)}$ and Svitlana Balinchenko ${ }^{2}$ \\ 1 Belt and Road Initiative Centre for Chinese-European Studies, Guangdong University of Petrochemical \\ Technology, Maoming 525000, China \\ 2 Philosophy Department, Yuriy Fedkovych Chernivtsi National University, Chernivtsi 58012, Ukraine; \\ sp.balinchenko@gmail.com \\ * Correspondence: bazaluk@ukr.net; Tel.: +38-050-325-16-56
}

Received: 18 March 2020; Accepted: 15 May 2020; Published: 18 May 2020

\begin{abstract}
The conflict-related internal displacement in Ukraine since 2014, after the armed combats with Russian military forces backing the separatist administrations, as well as the occupation of Crimea by the Russian Federation have not been state-organized. They imply a range of personal choices depending on civil positions and destinations for resettlement; therefore, the affected persons get involved in the consequent practical discourses and decision-making processes. Based on the legislative acts and the international reports on internal displacement, the internal displacement due to the current hybrid war of the Russian Federation against Ukraine is compared with the first Russia-backed separatist conflicts after the collapse of the USSR - the wars in South Ossetia, in 1992, and in Abkhazia, in 2008. The internal displacement situations have been reviewed through their dynamic coordination patterns, with regard to non-equilibrium transitions, fluctuations, and adaptations triggered on the systemic, community, and personal levels, as well as to the expected durable solutions: integration, return, temporary resettlement. Therefore, we suggest, for further discussion, the patterns of bistability—-for the internal displacement due to the Russo-Georgian wars of 1992 and 2008, characterized by an overfocus, in the practical discourses, on the return of the internally displaced persons (IDP), and metastability-for the conflict-related internal displacement in Ukraine, with both the return and local integration solutions creating the quasi-stable system.
\end{abstract}

Keywords: Ukraine; Georgia; internal displacement; bistability; metastability

\section{Introduction}

Since 2014, the Russia-backed aggression against Ukraine has stretched from the occupation of Crimea by the Russian Federation, in March 2014, to the military support of the separatists in eastern Ukraine, with further invasion. Russia's political backing of the de facto administrations in the non-government-controlled oblasts of Donetsk and Luhansk (the NGCA) has lasted from May 2014 until the current moment. The estimated number of individuals affected by the conflict, in 2015, was stated as 5 million people in need of humanitarian assistance, 1.5 million registered internally displaced persons (IDPs) in Ukraine, and 1.1 million people displaced to the neighboring countries [1]. Four years later, as of June 2019, according to the USAID Complex Emergency Fact Sheet on Ukraine, the numbers have remained high, the situation in Ukraine being described as follows: 3.5 million people in need of humanitarian assistance, 1.3 million IDPs, 480,156 Ukrainians seeking asylum in nearby countries, 1.1 million food-insecure people in eastern Ukraine, and 3,330 estimated conflict-related civilian deaths since April 2014 [2].

The International Organization for Migration (IOM) reports 1,437,406 IDPs as of 27 January 2020 [3], though the exact number of displaced individuals has yet to be properly distinguished. 
The indicator of permanent residence in the government-controlled areas of Ukraine (the GCA), according to the calculation of the UN's Office for the Coordination of Humanitarian Affairs (OCHA), includes about 800,000 registered and unregistered IDPs permanently living in the GCA [4]. In July 2019, according to the OCHA's report on Ukraine, the protracted displacement was recognized as such. This actualized the necessity of formulating durable solutions with attention to the indeterminate state of affairs concerning the status of the occupied territories and the general lack of predictability of the political and military moves of both the de facto administrations of the NGCA and their supporter, the Russian Federation. The Minsk I and Minsk II proved mostly ineffective. They were repeatedly breached by the actors [5-8], thus provoking the waves of displacement. Furthermore, the political course of Ukraine has been amended by the current government's attempts at a rather vague and hasty peacebuilding process, including the disputable compromise of the Schteinmeier Formula, the risks, and strategic goals being underestimated and partly ignored [9].

The IDP-related situation in Ukraine emerges from the relatively new hybrid war background created by the Russian Federation. The term hybrid warfare is still disputable. It has been used since 2005 to indicate "a blend of conventional/unconventional, regular/irregular, and information and cyber warfare" [10], and was actualized again in the context of the Russian intervention in 2014. Puyvelde recommends avoiding the term hybrid warfare and considers a war to be "a complex set of interconnected threats and forceful means waged to further political motives" [Ibidem]. Nevertheless, Dodonov, Kovalskyi, Dodonova, and Kolinko underline that the hybrid warfare of the Russian Federation is "a reconsidered version of the western concepts of non-linear/transformed war" [11]. In the Ukraine-related context, warfare is characterized by the impacts on the population of eastern Ukraine and Crimea by the Russian Federation, ranging from informational backup to the separatist groups, for instance, by actualizing the mythologemes of the Russian-speaking population being in need for defense, to the military support of the separatist movements by the Russian Federation and the actual armed combat in eastern Ukraine. At the same time, a specific feature of warfare is that the hybrid war is pictured in the Russian mass media as "the war of the West against Russia" [11] (p. 102).

Therefore, there are some important phenomena connected with internal displacement in the above-described context. In this article, the internal displacement-related issues are mostly referred to in terms of migration and communication studies. The influence of official regulations and discourses, as well as mass media, on the displacement-related decisions of individuals, is referred to in the article as a discursive (narrative-centered) impact. Integration is used in relation to the participation and incorporation of newcomers into the receiving society [12], as one of the acculturation strategies whereby individuals maintain their culture while supporting relationships with other groups [13]. Reintegration is a migration-related durable solution based on the processes of inclusion of the displaced persons into a community upon their return. The processes require the mutual accommodation of the returnees and the communities, which refers to a two-way adaptation and overcoming of otherness-related biases. Reterritorialization, on the other hand, implies spatial integration, for instance, when the official discourses lay the focus on the necessity of IDPs returning to their former place of residence. The sense of belonging to the former or current place of residence refers to the individual level of adaptation and implies an identification with the received community or with the one left behind. The gradation of belonging is understood after Grzymala-Kazlowska and Phillimore. Social anchoring/un-anchoring refers to the ability to integrate into the new community while "finding significant footholds which enable migrants to acquire socio-psychological stability" [12]; embedding refers to the experience of integration over time [12] and to the decisions of IDPs to extend their stay at a receiving community or return home. For Ukraine, however, the notion of hybrid/shuttling IDPs refers to the individuals living in the GCA near the contact line and paying a significant number of visits to their former place of residence in the NGCA, in order to maintain their housing and social links [14] (p. 28). Internal displacement is considered a source of super-diversity. In migration studies, the term refers to the transformation of communities under the influence of migration-related changes in the population [12]. For Ukraine, the arrival of IDPs from eastern Ukraine to culturally different regions triggered a restructuring of the communities, 
that is, a division into groups based on the attitude to the conflict and its participants. Schismogenesis refers, in the article, to the conflict-induced process of alienation and split in communities [11]. NIMBY ("Not in My Back Yard") refers to the biases as a result of the alienation. For instance, IDPs may be considered dangerous due to an accentuated image of a newcomer from a particular region [15].

In the article, a community restructured under the pressure of displacement-related social challenges is viewed as a destabilized non-equilibrium system. The fluctuations of the system refer to demographic and social changes in response to administrative decisions. The fluctuations may lead to the collapse or the stabilization of the system. Coordination dynamics refers to the recovery of the system after the impact. There are three types of stability in relation to internal displacement. Monostability refers to the situation when return is impossible or dangerous; this variant is typical for displacement due to human-made disasters and radical change of the environment $[15,16]$. Multistability refers to several possible scenarios of internal displacement, including partial and full displacement. Bistability refers to a two-mode version of multistability, when the present IDP status is considered a temporary one, before the preferable return in the future. Metastability refers to a quasi-stable pattern in the situation of a protracted displacement, where stability depends on the access of IDPs to decision-making and practical discourses. Metastability implies no preferable solution in the "integration vs. return" range of options.

The analysis of the narrative-centered character of internal displacement in Ukraine has the potential to contribute to the current ongoing discussions on migration, integration, and super-diversity, thus adding the dimension of discursive impact to the widely accepted "network-fluidity-mobility" set of issues considered within the frameworks of globalization, otherness, and migration studies fields. Moreover, within the wider spatial and temporal context of internal displacement, the current hybrid war of the Russian Federation against Ukraine can be compared with the first Russia-backed separatist conflicts after the collapse of the USSR - the war in South Ossetia, in 1992, and in Abkhazia, in 2008, having Russia and Georgia as actors. The protracted internal displacement, until nowadays, the process of formulating durable solutions to the conflicts, especially the measures concerning the intergroup and intragroup realization of otherness, and state officials' patterns of return influencing IDPs' adaptation to their current communities, are also relevant for a better understanding of the Ukrainian context of displacement.

\section{Materials and Methods}

The review of the conflict-driven internal displacement situation in Ukraine is based on three batches of data: (1) literary sources on migration-related issues; in particular, recent integration and super-diversity discussions and critiques applicable to the Ukrainian migration context; (2) normative documents and official reports on the conflict-related displacements, as well as the literary sources containing the analytical data enabling to establish spatial and temporal parallels with the current protracted internal displacement in Ukraine; (3) legislative acts, the official data of international monitoring missions, and investigations on the dynamics of discourse formation regarding the persons displaced from eastern Ukraine and Crimea, in the perspectives of their outward movement to the Russian Federation (refugees) and inward resettlement in Ukraine (IDPs).

The methodology implies a theoretical review of the migration, otherness, and integration issues; a synchronic and diachronic comparative analysis of the data, with the current protracted displacement situation in Ukraine to be compared with Georgia's, South Ossetia's, and Abkhazia's conflict-driven internal displacement (1992-2008-present); as well as discourse evaluation by means of tracing the otherness attitude shifts in the documents and monitoring data.

The internal displacement situations are viewed from the perspective of coordination dynamics, as the fluctuations, instabilities, adaptation, and other perturbation-related issues of a non-equilibrium system represented by a restructured community, and can be regarded with attention to the system's recovery after this specific migration-related impact. The methodology is based on the assumption that dynamic coordination studies have long outreached the scope of issues on the realization of 
competing brain-related tendencies influencing behavior by means of the mind, such as intention-based changes and adaptation skills [17], and the secondary decision-making in its relation to the confidence of the prior decisions [18]. The studies on multistability and metastability have become modeling tools applicable to a wide range of body-mind-environment patterns involving social patterns [19], economic processes [20], schismogenesis tendencies based on multistability, and social interactions in the informational space [11,21].

\section{Theoretical Background}

Although in the EU Press Release on Justice and Home Affairs of November 19, 2004, integration was described in relation to immigrants and national citizens as "a dynamic, long-term, and continuous two-way process of mutual accommodation, not a static outcome" [22], the migration-related issues have been considered in migration studies and official discourses with attention to the benefits and strains for both IDPs and receiving communities. The migrants' contribution to the community, their "visibility" through employment rates and decision-making, and the traditional set of "cooperation-coordination-communication" are the central issues within the integration framework [22]. The recent wave of integration rethinking has been based on a critique of the approach describing immigrants as aliens and imposing adjustment claims violating the principles and provisions of dignity, equality, liberty, and fundamental rights.

The current tendencies make it important to study the grounds for the "two-way mutual accommodation" idea, through a critical remodeling of the integration discourse by means of the adoption of a network [23], mobility [24,25], and fluidity [26] claims, as well as by scrutinizing the diversity and super-diversity problematics [12,27-30] on the cross-national (migrants/citizens) level. The intra-nation dimension (citizens from culturally different regions in forcibly restructured communities; newcomers/locals) includes the internal displacement aspect of migration. It can be regarded in a variety of contexts, ranging from conflict-driven displacement to massive resettlement associated with industrial projects. The social impacts on IDPs and host communities need to be evaluated based on the near/remote, voluntary/obligatory, single/repeated character of the movement [11,14-16,31]. In 2017, Grzymala-Kazlowska and Phillimore stated in their review on integration-related tendencies that the emergence of a new demographic reality requires not just a description of the "migration-driven complexifications of population" [12], but also super-diversity-based amendments to the way a society deals with fluidity and super-mobility. Among the social impacts of the complexification process, one should take into account an earlier idea by Kim, namely the idea of increased personhood, arising from human conditions which require the cultural parameters to be revised and transformed in a way that allows for the building of a new identity while restoring the old one [32].

For Ukrainian society, a massive internal resettlement preceded the current one: the centralized displacement of the Ukrainian population from the Chornobyl exclusion zone in 1986-1987, due to the human-made disaster. This migration is known for the lack of information given to the affected communities about the danger of radioactive contamination and the scope of the disaster, for the delay in the authorities' reaction, and for the absence of any deliberation on the situation of forced migration. For instance, the Chornobyl NPP accident took place on April 26, 1986, and the population was forced into an outer-organized displacement only after May 5, 1986, without any mention of lifeworld decisions or a potential return. The National Program appointed to deal with the consequences of the Chornobyl NPP accident provides the data of 163,000 displaced persons as of January 1990, but there were 2.6 million living in the contaminated area with more than 1 Ci/sq.m. of cesium-137 [33,34]. The unconditional (obligatory) eviction contrasted with the guaranteed voluntary resettlement zone, where the authorities' pressure was mainly financial, as the legal acts of 1986-1991 suggested the right to assistance in resettlement and employment, as well as compensations for the property and cattle lost due to the contamination [35-37]. Therefore, a pattern of monostability was established, the return to the contaminated areas of the exclusion zone being considered not only undesirable, but also illegal. 
Thus, resettling and rebuilding one's social space and lifeworld remained the only preferred and legally supported option.

The current conflict-related actualization of fluidity, the massive restructuring of communities under the impact of several migration waves, and the various internal displacements are associated with the stages of military and political combats with the Russian Federation since 2014 (Figure 1).

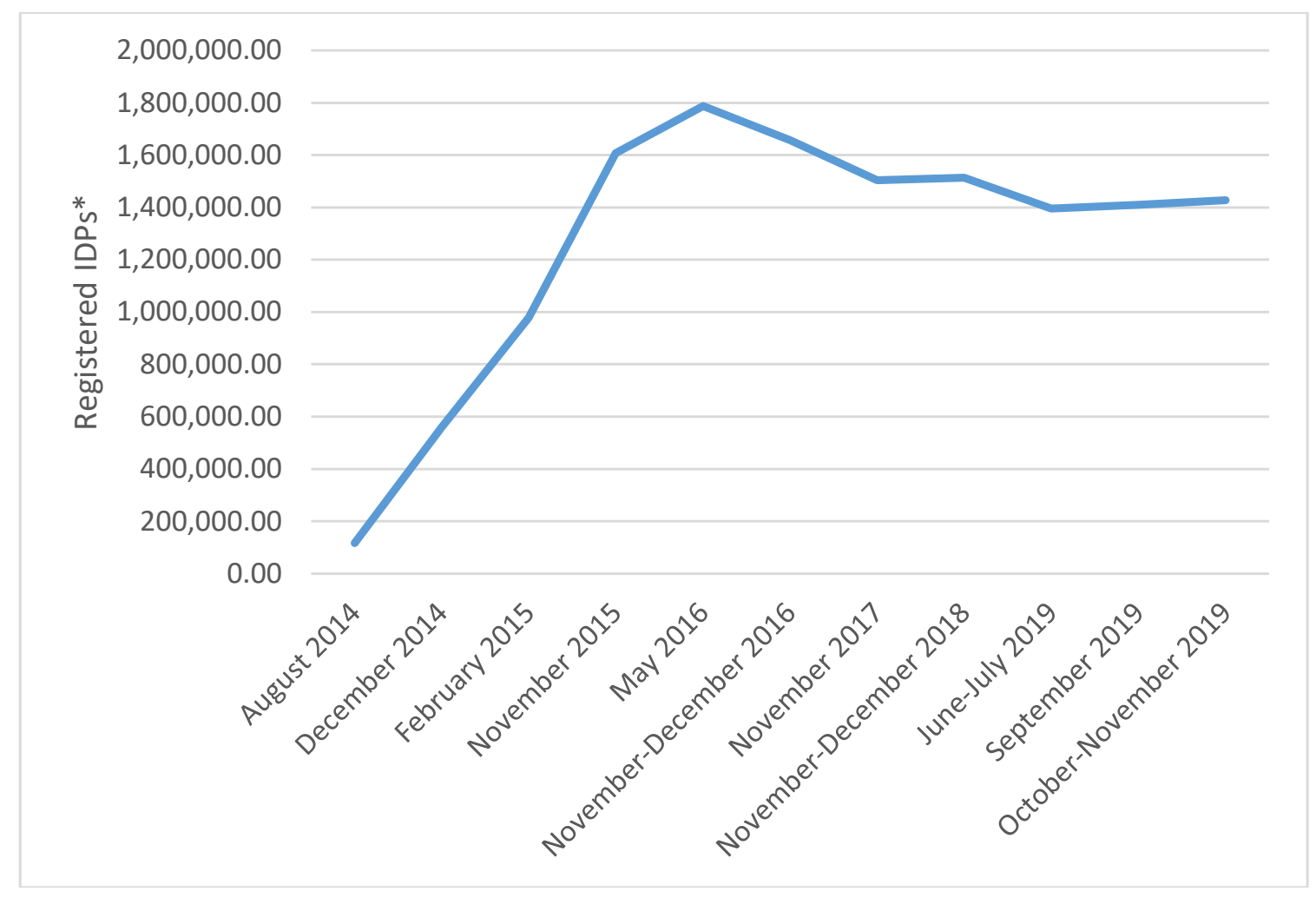

Figure 1. Internal displacement dynamics in Ukraine, 2014-2019. * The data sources: August 2014, 117,000 IDPs [38] (p. 40); December 2014, 564,353 IDPs [39]; February 2015, 978,482 IDPs [38] (p. 40); November 2015, 1,607,265 IDPs [40]; May 2016, 1,787,019 IDPs [41]; November-December 2016, 1,656,662 IDPs [42]; November 2017, 1,504,015 IDPs [43]; November-December 2018, 1,513,574 IDPs [44]; June-July 2019, 1,395,099 IDPs [45]; September 2019, 1,410,615 [46]; October-November 2019, 1,427,211 [47].

The migration-related tendencies of belonging gradation and assessment, particularly "embedding" and "anchoring" [12], are relevant for IDP-status evaluation in the situation of protracted displacement, where the sense of belonging to the current place of residence requires the unanchoring from the former place of residence (see in Figure 2 the trace of unanchoring from the former place of residence, starting in 2019 and being prognosticated as a tendency). This involves restructuring social links and individual/collective narratives in the new social cohesion contexts, and the consequent reterritorialization, rather than reintegration. Thus, spatial and temporal limitations lead either to the camp-like separation and marginalization of the newcomers on the basis of their collective memory or to visibility in the diverse structure of the host community, as opposed to assimilation and isolation, due to the "war experience" of the IDPs being incomprehensible to the local (non-affected) population. 


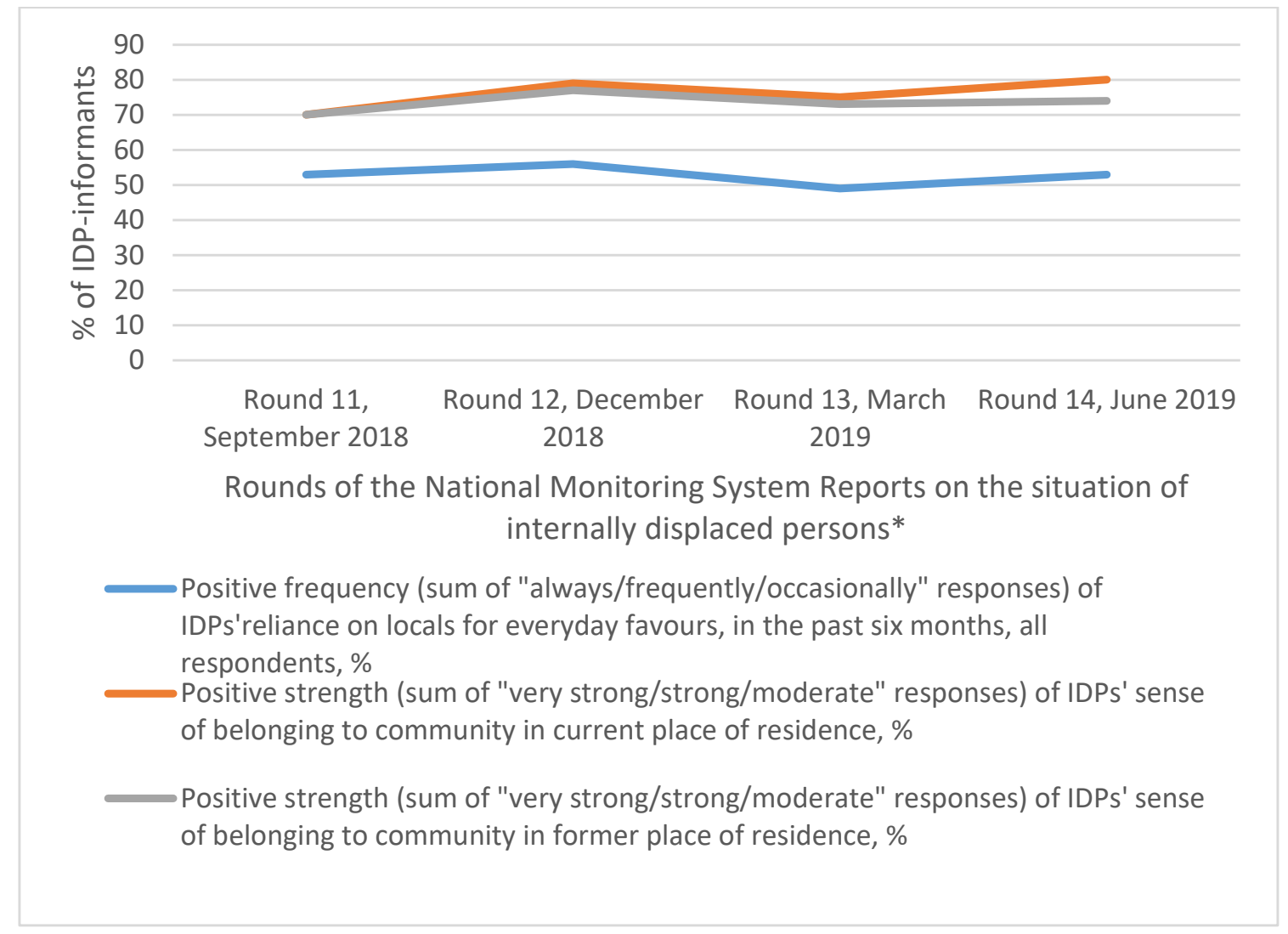

Figure 2. IDPs' sense of belonging and reliance on locals, 2018-2019. * See [48-51].

The forced migration problematics and migrants/host communities relations can be found in the recent migration studies in a variety of aspects: the bureaucratically-imposed and displacement-specific disadvantages of forcibly displaced persons [52]; intergroup relations within host communities, connected with stereotypic or faltering perceptions of the host communities by migrants, and vice versa, in correlation with subjective well-being and the length of stay [53]; and the context of prejudices and negative attitudes towards the newcomers in the host communities. Regarding the armed conflict-related displacement in Ukraine, it is necessary to refer to the range of works on displacement problematics relevant to the situation; among them, the description of incremental integration specifics should be pointed out, as de jure and de facto local integration issues are considered inapplicable to the IDP citizens by the researcher [54] (p. 24). Another important study of conflict-driven internal displacement, by Rajput, contains an important distinction between a forced eviction and a voluntary flight or conflict-induced displacement, the latter not only indicating a deep social problem, but also being a result of the transformation of both the displaced persons (IDPs) and the communities [55]. The Ukraine-specific investigations include those on attitude formation, "Not in My Back Yard" (NIMBY) effect presuppositions, ways of overcoming discrimination, and the comparison of the IDPs from eastern Ukraine and Crimea [14,15,56]; one study focuses on the shift of the positive attitudes of Russian communities toward the refugees from eastern Ukraine to negative ones [57], the pattern partly coinciding with the "euphory-aggression-indifference" change pattern in the host communities $[58,59]$.

As for the comparative aspect, the Russia-backed separatism of South Ossetia and Abkhazia, with displacement patterns and contexts comparable with the Ukrainian ones, can be viewed based on the legislative acts and the practical discourses "Russia - Georgia" and "Russia - de facto administration", as presented in the publications, comments, and discussions on the diplomatic level [60,61]: analytics on the legal aspects of the separatists' regions [62]; life stories of IDPs [63], analytics on internal displacement and citizenship issues [64,65]. 


\section{Results: Coordination Dynamics of Internal Displacement}

The internal displacement patterns have been traced in their dynamic coordination, and in accordance with the apprehension of the internal displacement situations as a series of non-equilibrium transitions, fluctuations, and adaptations, or lack thereof. A system can be viewed in regard to its potential to recover after the significant perturbation and, contextually, to restructure the communities and shape future migration-related durable solutions (local integration, return, temporary resettlement, reintegration) in the practical discourses and legislation. Thus, the dynamic coordination of internal displacement is as follows:

(1) Bistability-regarding the internal displacement due to the Russo-Georgian wars of 1992 and 2008, followed by the ethno-focal issues on the agenda of the de facto administrations of Abkhazia and South Ossetia, and the intensive official rhetoric of IDPs' return in Georgian and international discourses;

(2) Metastability - the internal displacement triggered by the armed conflict in eastern Ukraine between Ukrainian military forces and Russian military forces backing the separatist administrations, as well as by the Russian occupation of Crimea; both the return and local integration scenarios are present in the practical discourses.

Taking into account that, after the coordination dynamics, the transition from more stable dynamic phases to less stable ones takes longer than the reverse $[17,18]$, the protracted internal displacement contexts can imply (1) a non-equilibrium phase, (2) fluctuation(s) of the system through multistability or bistability, and (3) a quasi-stable phase of metastability. The phases can be described as follows:

(1) A non-equilibrium phase of eviction/displacement/resettlement leads to a perturbation of the social links and the actualization of the forced/voluntary movement attractor, this being regarded as the first stage of the decision-making sequence characterized by the intention, confidence, and success of a trial, which can further influence the decisions and is reflected in further attitudes regarding the return (it can be both a successful and a failed trial scenario, depending on the intention and sense of belonging) or the persistent integration into the local community.

(2) Fluctuations take place when the system becomes unstable due to the displaced population influx into local communities. The bistability of the system means that two coordinated states coexist, for instance, return and integration, though there is a schismogenesis-like pressure aimed at promoting one of the options (e.g., obligatory/necessary return), which is absorbed by the system as a pattern. In this situation, practical discourses lead to a decision-making "prolapse," when the displacement is considered a temporary state, regardless of its actual duration in decades. Thus, the adaptation and normalization of life under the current conditions become problematic. Multistability implies a coexistence of various scenarios and allows for switching between them. For instance, it can be traced in the economic-driven quasi-displacement of "hybrid IDPs." Therefore, conflict-affected persons can abort a full displacement scenario due to the lack of confidence in the successful trial, or fear of the financial or social obstacles to displacement;

(3) A durable quasi-stable stage of protracted internal displacement can be described as metastability. On the one hand, in the theory of dynamic coordination of brain and cognition, it implies "the simultaneous realization of two competing tendencies: the tendency of the individual components to couple together and the tendency for the components to express their independent behavior" [17] (p. 913); on the other hand, in the social perspective, there tends to form a "small-world"-like topology, including rather distinct groups with a potential of counteracting excessive convergence.

The metastability stage can undergo a transition into monostable or bistable stages. For instance, monostability with the negligible possibility of the displaced persons returning to the former place of residence emerges when, for example, assimilation makes the displaced persons invisible in the community, IDP-status registration becomes irrelevant, return is impossible, there is a high level of 
adaptation to the local community with a decreasing sense of belonging to the former place of residence, identity shifts take place, the "integration vs. return" bifurcation becomes actual after the cessation of the key conflict cessation and the emergence of a reconciliation scenario, or when IDP-status fails to contribute to the metastability under the renewed conditions.

\section{Internal Displacement in Georgia Due to Russia-backed Separatism (1992; 2008): Bistability Pattern of Resettlement}

The internal displacement concept in Georgia has been legislatively complicated, as IDP-status, after Georgian legislation, is not applicable to the persons affected by natural and human-made disasters [64] (p. 50). Therefore, the internal displacement is to be understood exclusively as conflict-related, in contrast to the UN Guiding Principles on Internal Displacement [66]. The waves of internal displacement in Georgian regions, triggered by the wars in 1992 and 2008, developed as follows:

(1) early 1990s: 60,000 displaced persons due to the 1989-1992 war in South Ossetia, i.e., the displacement accompanied with ethnical cleansings; over 250,000 persons affected by the 1992-1993 war in Abkhazia;

(2) early 2000s: August 2004-government-supported relocation of women and children from the ethnic Georgian villages in South Ossetia; August 2008-158,000 displaced persons, Georgians and Ossetians [64] (p. 16).

Thus, the internal displacement situation has been influenced by the trajectory of the conflicts and is still under the impact of the incompatible intentions of the conflict parties $[61,63,65,67]$. In the 2009 Internal Displacement Monitoring Center Profile of the internal displacement situation in Georgia, a review of the regulatory forces was suggested, which is still actual ten years later. Being return-focused, the situation has a bistability pattern, with IDP-status and return being the prevailing solutions under discussion. There are several important dimensions to the situation.

(1) The Georgian government stresses the necessity for the IDPs of all the displacement waves to return to their homes, as Abkhazia and South Ossetia are regarded as the territories meant to be under Georgian control. Local integration of the IDPs is on the agenda as a temporary solution, still compatible with further return $[61,64,67]$.

(2) For Abkhazia's de facto administration, the return of IDPs is considered problematic, if possible. There is a negative attitude to Georgians, as well as the demands of the administration that the returnees give up their Georgian citizenship and obtain the local "passport," thus hindering the IDP reintegration process $[61,64,67]$. Moreover, in the so-called "Law of the Republic of Abkhazia on Citizenship of the Republic of Abkhazia," in Article 6, there are the provisions stating that dual citizenship is only possible for the citizens of the Russian Federation [68].

(3) South Ossetia's de facto administration has adopted an ambiguous approach to returnees: after the war, return was declared impossible. Later, nevertheless, the rhetoric changed, and the right to return was formally acknowledged, though the practical implementation of reintegration did not follow [64] (p. 47). At the same time, the integration with the Russian Federation widened. For instance, on December 28, 2018, in the Law on the Amendment to the Treaty on alliance and integration between the Russian Federation and the Republic of South Ossetia, the absence of limitations for the period of stay of the citizens of the Russian Federation in the self-proclaimed republic was ratified [69]. And in the so-called "Law of the Republic of South Ossetia on Citizenship of the Republic of South Ossetia", in Article 16, the grounds for refusal to grant citizenship of the Republic of South Ossetia include the position of a person against the sovereignty of South Ossetia, as well as a citizenship of another state other than South Ossetia or the Russian Federation [70].

The Quadripartite Agreement on the Voluntary Return of Refugees and Displaced Persons of 4 April 1994, having actually failed due to disagreement of the parties on the implementation of the repatriation 
plan, the discourses of return and resettlement became influenced by the processes of exclusion on the local level [64] (p. 48). Since displacement was granted the features of a protracted displacement, in 2002, local integration was not considered possible, and Georgia's deputy minister for employment and settlement of displaced persons stated the following: "The only solution is to return the IDPs to their homes" [67], thus supporting the return-centered rhetoric. In 2007, the situation changed with the adoption of the national strategy on IDPs by the Georgian government. The integration was considered by the Georgian official bodies to be a solution compatible with the future return. Still, its implementation was delayed and hindered with the second wave of IDPs after the Russo-Georgian war of 2008. The strategy was further supported in 2009, with the primary option of return and the possibility for the displaced persons of both waves of forced migration to be reintegrated [64] (p. 51).

The pursuit of the goal aimed at returning IDPs to their homes, though supported by IDPs, distinguishes this conflict-driven internal displacement from the Ukrainian one, as in Ukrainian legislation the legal equivalent of the durable solutions of return or local integration is based on personal decision-making on the part of the affected population [71,72]. Despite the difference, there are several common features in the internal displacement situations and intentions of the displaced persons. Among them, there is an unwillingness to live under the de facto rule of the separatist administrations, due to the threat of violence and lack of rule of law [64] (p. 45); and IDPs' refusal to register, in the situation of secondary displacement, for fear of losing benefits and payments, which leads to a lack of veritable and accurate IDP-related statistics [4,64]. The dependence of migration patterns on employment and housing opportunities also played a significant role. For instance, in Georgia, Kutaisi is farther from the conflict zone, but it was regarded as a favorable place on the grounds of available living space [64] (p. 22). A similar correlation is seen in Ukraine. Lviv, in contrast to other oblast centers of western Ukraine, has been regarded as a more popular place for IDPs' resettlement owing to the housing and employment opportunities, despite the fact that the city is farther from the former place of residence of the IDPs [50,51].

The Russian trace in both situations of internal displacement implies that both Ukraine and Georgia face the hybrid informational distortions aimed at destabilizing the population of the regions and affecting long-term solutions. Moreover, in the context of Russia-backed separatism, occupation, and forced migration, the situations in both countries have much in common [60,61]. As for the Georgia-related context, for instance, in the UN General Assembly plenary session report of June 2019, Russia is recognized as "the occupying power," and the session participants voiced demands for the Russian Federation to stop conducting illegitimate polls (so-called elections) and erecting illegal border marks in the occupied territories [61]. Nevertheless, the process of submission and further integration of the separated territories of Georgia into the Russian Federation should obviously be traced back to a series of agreements, among which the August 122008 ceasefire agreement with the points on the future status of the "breakaway territories" and full respect for the sovereignty and territorial integrity of Georgia having been excluded by Russia [73]. In 2016, the Ministry of Foreign Affairs of the Russian Federation stated that the agreement is "mythical" and "there is no such document". In the same comment, "the territorial disintegration of the country" into "two independent states" was considered the "irreversible consequence" of the August 2008 events [60].

The position of the Russian Federation as a "guardian" of the separated and occupied territories of the neighboring countries, as well as the post-Soviet space reintegration, attempts made by the Russian Federation by means of a purposeful and systematic implementation of strategic assumptions aimed at the disintegration of the neighboring countries, along with conventional military attacks [74] (p. 48), can be applied to both Ukraine and Georgia. The changes in the legislation of the Russian Federation illustrate the attempts to create the normative basis for the annexations. In the context of Ukraine, it is worth mentioning the hasty treaty of admittance of the newly-recognized "republic" of Crimea as a subject of the Russian Federation on the subsequent date of March 17-18, 2014 [75]. In the Georgian context, the important treaties refer to recognizing the self-proclaimed republics and forcing their military, economic, and political assimilation with the Russian Federation [69,76-78]. 
Therefore, the bistability pattern of internal displacement in Georgia has been affected by a wide range of factors. Among them, the hybrid impact of the Russian Federation, the acknowledgment of the de facto administrations, and the vetoing of international discussions and missions on the issues. The focus laid by the Georgian authorities on return as an exclusive durable solution tends to impair lifeworld normalization in the protracted displacement situations. Local integration in this situation was regarded as a temporary option before the final opportunity to return, thus forming the transit syndrome of "postponed life" for the affected populations.

\section{Internal Displacement in Ukraine Due to Russian Military Aggression (2014-Present): Metastability Pattern of Resettlement}

The displacement due to the hybrid war started in March 2014 and was not state-regulated. Thus, it formed a particular pattern for decision-making on the displacement of the affected population and a multi-layered range of intentions and decisions arising from the possibility of the subjects not being coerced into displacement (eviction, evacuation, or resettlement) in a centralized manner. The correlation between the decision and the resources available is especially relevant in this context. Therefore, this displacement fell mostly under the limitations imposed by the family situation and the social-cultural and political biases of those affected. The range of choice varied from the scenarios of abandoning property, separating from family members with opposite views and priorities, going eastwards/westwards, staying at home, and sacrificing one's own decisions in order to maintain the components of the lifeworld intact. The decisions were greatly influenced by the necessity of choosing between an IDP and a refugee status while deciding on the direction of the displacement.

The metastability of internal displacement in Ukraine is correlated with the general "tiredness of the issue" in Ukrainian society. The attitudes to the conflict's outcome and the affected groups are value-laden, and the relevance to the citizens of concepts like freedom, integrity, solidarity, or justice, can be projected onto the importance of some key social issues induced by the war. For instance, the public opinion surveys to assess the changes in citizens' awareness of civil society and their activities showed a shift in the evaluation of the response to the topic "Crisis in the Donbas." In the question set on the three most important current issues "for Ukraine/for you and your family," the issue shifted from the third place in 2017 and 2018 (49\% and 46\% of the respondents, correspondingly), to the "fork" of importance distribution in 2019 (the second place, 48\%, for the question concerning the most important issues for Ukraine, and the fourth place, $27 \%$, in the rating of personally important issues, after health care, fighting corruption, and pension issues), despite the ongoing conflict in the country $[79,80]$. The same surveys demonstrate an even more dramatic decrease in the involvement with the issue of "Returning Crimea": from $10 \%$ of respondents mentioning it among the three most important issues for Ukraine in 2018 and 2019, to 5\% mentioning it among the issues important on the personal level $[79,80]$. Nevertheless, the scenarios of integration of the NGCA in the Russian Federation or of the NGCA gaining an independent status lack support even in the oblasts of Ukraine closest to the conflict zone; for instance, there has been a decrease of such support in the Dnipro oblast, from 2.2 to 1.5 points, in 2017-2018, and in the Luhansk oblast, from 2.5 to 2.0 points, in 2017-2018, after the data of the UN SCORE for Eastern Ukraine [81].

Furthermore, for peace be understood as "a coordinated interaction between mental spaces that leads at a minimum-to respect, at a maximum-to the multiplication of the manifestations of each other" [82], it is also necessary to evaluate the "Not in My Back Yard" (NIMBY) issue in Ukraine, in the context of internal displacement. There is an entire range of otherness assumptions in the communities.

(1) The IDP group's members are considered "both victims and perpetrators" [14] (p. 27); due to the prejudices concerning the accentuated image of those able to transfer the social order of the Donbas, the latter are believed to be criminally threatening to the host communities; the stigmatization of the IDPs from the Donbas, "not able to defend Ukraine," in some cases lead to the silencing of the separatist past $[14,15]$. Nevertheless, the results of the National Monitoring System Reports (NMS reports) on the situation of internally displaced persons, in 2019, demonstrated a high level 
of trust placed on the IDPs by the local population, reaching $61 \%$ [51] (p. 46). Up to $22 \%-23 \%$ of IDP-informants intended to return to the former place of residence in the future, compared with $34 \%-36 \%$ who had no intention to return even after cessation of the conflict $[50,51]$.

(2) The "burden of survival" and "contamination" with the region of earlier residence [14] (p. 58), as well as the life-death experience of war-fleeing survivors, caused the pattern of firstly positive generalization toward the group in the receiving communities to change to negative assumptions and prejudices, and led to the invisibility or further exclusion of the migration-specific issues from the agendas [15] (pp. 51-54). The same pattern can be traced in the case of Ukrainian refugees in the Russian Federation, from help and consolidation, in 2014, to resentment, in 2015 [57] (pp. 105-107). Even the traditionally supportive communities of the GCA of the Donetsk region, with the highest density of internally displaced populations, showed a drop in positive attitude toward the IDPs, from 7.9 to 7.5 points, in 2017-2018 [81]. There was also a decrease in contacts between the local population and IDPs in the Luhansk region of the GCA, from 4.6 to 3.9 points, in 2017-2018 [81], but this tendency might indicate the assimilation and, therefore, the invisibility of the IDP group in the communities, and not a widening of the gap between the locals and the newcomers.

(3) "Marker of displacement" in social services, following the Resolutions of the Cabinet of Ministers of Ukraine, highlighting the necessity of regular physical checks on IDPs and their living conditions in order to obtain benefits and payments [83]. It should also be taken into consideration the criminalizing of IDPs in the mass media, especially during the early stage of displacement, and further otherness grading, with different attitudes to the IDPs from Crimea and the Donbas in the receiving communities $[14,15,58]$.

(4) Invisibility of the IDPs in the communities where their percentage is low and exclusion from decision-making; readiness of the current authorities in Ukraine for decisions leading to ambivalent consequences, and therefore able to "seduce Russia and the West to press Kyiv for concessions" [84] (p. 702).

Based on these tendencies, we can consider the balance between the integration and return options in the internal displacement situation, with the special significance of the metastability point, correlated with the participation of IDPs in decision-making on displacement-related issues, NIMBY-related triggers and civic and political engagement.

The dynamic coordination approach to internal displacement as metastability makes it possible to eliminate the vision of migrants (in particular IDPs) as a "problem," a "burden," as people "in need of adjustment," and suggest the vision of this group instead of as a potential source of social capital diversification and a mobility catalyzer, towards renewed, dynamic, and fluid versions of social cohesion [85].

\section{Conclusions}

Based on the dynamic coordination aspects that can be traced in the protracted internal displacement contexts under analysis, the conclusions can be presented as follows.

Firstly, the conflict-driven internal displacement in Ukraine has the modularity of the metastability type. It forms a quasi-stable durable pattern with metastability point $\alpha$ (decision-making participation), the perturbation of which can shift the system into the multistability (bistability) of "return vs. integration." For instance, a lack of confidence in the first-order decision-making-displacement itself or its direction-for those having considered moving to the government-controlled regions of Ukraine, the Russian Federation, or the other neighboring states, can lead to instability in the decision-making on the secondary level. The instability leads to the formation of the group of "hybrid IDPs" with displacement bifurcation, the persons shuttling between the GCA and the NGCA in search of financial and administrative benefits. The metastability model of internal displacement tends to be overestimated as a successful integration model, and therefore omitted from durable solutions and prospective 
post-conflict scenarios. Nevertheless, the situation remains ambiguous due to a range of factors. Among them, (1) integration-related factors: a minority/majority situation in the near-contact-line settlements where IDPs form a majority in the local community; invisibility, assimilation, excessive convergence, lack of random links between distinct groups; (2) return-related factors: the need, rather than the choice, to return; social or economic pressure in the host communities due to the elimination of the trigger for displacement-the cessation of the armed conflict; social space restoration in the former place of residence-gathering of previously displaced persons significant to an IDP; and (3) deviations in IDP-status: cessation of payments, change in registration status, reconciliation of conflict, and actualization of reintegration. The factors can trigger a new non-equilibrium phase, and the previous state of social cohesion recovery gets compromised, the critical point of instability having been reached beyond the reversible social perturbation threshold.

Secondly, another comparative aspect, the protracted internal displacement in Georgia due to the Russo-Georgian wars of 1992 and 2008 demonstrates a bistability displacement pattern. The focus on return as the key final outcome turns the protracted displacement into a durable state of quasi-temporary waiting for the possibility to return, and therefore, return as a governmental program, not eliminating the possibility of local integration altogether, keeps he IDPs in the situation of instability and maladaptation [64]. Thus, the multistability of the internal displacement concept has been discoursively tailored to fit the "IDP-status-return mode" scenario, with local integration presented mostly as a temporary transit solution.

To summarize, in the article, through the coordination social dynamics perspective, the following internal displacement modes were distinguished:

(1) integration mode: sense of belonging to the current place of residence; IDP-status being irrelevant; groups involved-IDPs with a negligible possibility/intention of return, integrated/reintegrated populations; coordination model-monostability;

(2) return mode: "necessary/rightful/dignified/safe return" of the IDPs to the former place of residence as the only solution and desired outcome promoted in the official discourses; sense of belonging to the former place of residence in the conflict-affected areas; groups involved-"temporarily" displaced persons, shuttling IDPs; coordination model-bistability;

(3) IDP-status mode: ambiguous quasi-stable state without preferable solutions; both integration in the local community and return are supported in legislation; groups involved-IDPs, local communities, official bodies promoting representation and participation of IDPs in decision-making; coordination model-metastability.

The framework is based on a comparison of the IDP-related policies, and it can be regarded as a suggestion for future researchers of internal displacement in other countries. The first and the second modes imply an impact of the discourses centered around the idea of either integration or return. The situation of a protracted displacement causes an overfocusing on the future goal, which at present "denies IDPs the ability to enjoy their full rights as citizens" [64] (p. 46), and impairs the actual lifeworld due to the "postponed life" syndrome of internal displacement. The metastability-related durable solutions imply several options. The integration in the local communities is still one of the core issues, and the focus is laid on social cohesion and reconciliation. A dignified return to the former place of residence during the post-conflict phase is also regarded as a legally acceptable option. Therefore, IDPs' access to the migration-relevant decision-making processes is vital to transform the quasi-stable state in a way that fits the sustainable development Goal 16, Peace, Justice, and Strong Institutions [86]-especially in Targets 16.8 and 16.9, on recovering conflict-affected areas in eastern Ukraine, as well as the strengthening of social stability and the promotion of peacebuilding and community security [86] (p. 109).

This study can contribute to further surveys and analyses of the migration tendencies resulting from military conflicts and human-made disasters and to the understanding of community-restructuring 
processes, taking into account the identity and sense of belonging fluctuations, as well as the impact of practical discourses on the migration-related decision-making processes.

Author Contributions: Conceptualization, O.B., S.B.; methodology, S.B.; investigation, S.B.; resources, O.B.; writing —original draft preparation, S.B.; writing—review and editing, O.B.; funding acquisition, O.B.; project administration, O.B.; supervision, O.B. All authors have read and agreed to the published version of the manuscript.

Funding: The APC was funded by the Guangdong University of Petrochemical Technology.

Conflicts of Interest: The authors declare no conflict of interest. The funders had no role in the design of the study; in the collection, analyses, or interpretation of data; in the writing of the manuscript, or in the decision to publish the results.

\section{References}

1. USAID. Ukraine-Conflict Fact Sheet \#1; USAID: Washington, DC, USA, 2015. Available online: https://www. usaid.gov/sites/default/files/documents/1866/ukraine_fs01_11-19-2015.pdf (accessed on 19 January 2020).

2. USAID. Ukraine-Complex Emergency Fact Sheet \#2; USAID: Washington, DC, USA, 2019. Available online: https://www.usaid.gov/sites/default/files/documents/1866/ukraine_ce_fs02_06-24-2019.pdf (accessed on 19 January 2020).

3. IOM's Assistance to Conflict-Affected People in Ukraine; Bi-Monthly Report; IOM/Ukraine: Kyiv, Ukraine, 2020. Available online: http://iom.org.ua/sites/default/files/iom_ukraine_assistance_report_december_2019_ -january_2020_eng.pdf (accessed on 31 December 2019).

4. The Difficulties of Counting IDPs in Ukraine; Global Report on Internal Displacement (GRID); Internal Displacement Monitoring Centre: Geneva, Switzerland, 2018. Available online: http://www.internaldisplacement.org/global-report/grid2018/downloads/report/2018-GRID-spotlight-ukraine.pdf (accessed on 18 January 2020).

5. Schoen, D.E.; Kaylan, M. Return to Winter: Russia, China, and the New Cold War against America; Encounter Books: New York, NY, USA, 2015.

6. Bentzen, N. Ukraine and the Minsk II Agreement: On a Frozen Path to Peace? European Parliamentary Research Service: Brussels, Belgium, 2016. Available online: http://www.europarl.europa.eu/RegData/etudes/BRIE/ 2016/573951/EPRS_BRI(2016)573951_EN.pdf (accessed on 19 January 2020).

7. Dempsey, J. Judy Asks: Can the Minsk Agreement Succeed? A Selection of Experts Answer a New Question from Judy Dempsey on the Foreign and Security Policy Challenges Shaping Europe's Role in the World; Carnegie Europe: Brussels, Belgium, 2017. Available online: https://carnegieeurope.eu/strategiceurope/68084 (accessed on 19 January 2020).

8. Malyarenko, T.; Wolff, S. The logic of competitive influence-seeking: Russia, Ukraine, and the conflict in Donbas. Post-Sov. Aff. 2018, 34, 191-212. [CrossRef]

9. Nelles, M. Expert QEA: Will the Steinmeier Formula Bring Peace to Ukraine? Atlantic Council: Washington, DC, USA, 2019. Available online: https://www.atlanticcouncil.org/blogs/ukrainealert/expert-qa-will-thesteinmeier-formula-bring-peace-to-ukraine/ (accessed on 19 January 2020).

10. Van Puyvelde, D. Hybrid War-Does It Even Exist? NATO Review. 7 May 2015. Available online: https://www.nato.int/docu/review/articles/2015/05/07/hybrid-war-does-it-even-exist/index.html (accessed on 2 May 2020).

11. Dodonov, R.; Kovalskyi, H.; Dodonova, V.; Kolinko, M. Polemological Paradigm of Hybrid War Research. Philos. Cosmol. 2017, 19, 97-109.

12. Grzymala-Kazlowska, A.; Phillimore, J. Introduction: Rethinking integration. New perspectives on adaptation and settlement in the era of super-diversity. J. Ethn. Migr. Stud. 2017, 44, 179-196. [CrossRef]

13. Sam, D.L.; Berry, J.W. Acculturation: When Individuals and Groups of Different Cultural background Meet. Perspect. Psychol. Sci. 2010, 5, 472-481. [CrossRef] [PubMed]

14. Ivashchenko-Stadnik, K. The social challenge of internal displacement in Ukraine: The host community's perspective. In Migration and the Ukraine Crisis. A Two-Country Perspective; Pikulicka-Wilczewska, A., Uehling, G., Eds.; E-International Relations Publishing: Bristol, UK, 2017; pp. 25-48.

15. Bulakh, T. 'Strangers among ours': State and civil responses to the phenomenon of internal displacement in Ukraine. In Migration and the Ukraine Crisis. A Two-Country Perspective; Pikulicka-Wilczewska, A., Uehling, G., Eds.; E-International Relations Publishing: Bristol, UK, 2017; pp. 49-61. 
16. Huang, Y.; Lin, W.; Li, S.; Ning, Y. Social Impacts of Dam-Induced Displacement and Resettlement: A Comparative Case Study in China. Sustainability 2018, 10, 4018. [CrossRef]

17. Kelso, S.J.A. Multistability and metastability: Understanding dynamic coordination in the brain. Philos. Trans. R. Soc. B Biol. Sci. 2012, 367, 906-918. [CrossRef] [PubMed]

18. Insabato, A.; Pannunzi, M.; Rolls, E.T.; Deco, G. Confidence-Related Decision Making. J. Neurophysiol. 2010, 104, 539-547. [CrossRef] [PubMed]

19. Paranyushkin, D. Metastability of Cognition in Body-Mind-Environment; Network Version; Nodus Labs: Berlin, Germany, 2012. Available online: https://noduslabs.com/wp-content/uploads/2018/04/MetastabilityCognition.pdf (accessed on 19 January 2020).

20. Cavalli, F.; Naimzada, A. Complex dynamics and multistability with increasing rationality in market games. Chaos Solitons Fractals 2016, 93, 151-161. [CrossRef]

21. Paranyushkin, D. Identifying the Pathways for Meaning Circulation Using Text Network Analysis; Network Version; Nodus Labs: Berlin, Germany, 2011. Available online: https://pdfs.semanticscholar.org/97ba/ 9f29c55ccbdd963e01f98cf17e73998f0f7d.pdf (accessed on 19 January 2020).

22. EESC. Press Release: 2618th Council Meeting Justice and Home Affairs; EESC: Brussels, Belgium, 2004. Available online: https://www.consilium.europa.eu/ueDocs/cms_Data/docs/pressData/en/jha/82745.pdf (accessed on 19 January 2020).

23. Ferguson, N. The Square and the Tower: Networks, Hierarchies and the Struggle for the Global Power; Allen Lane, an Imprint of Penguin Books: London, UK, 2017.

24. Bauman, Z. Liquid Modernity; Polity Press: Cambridge, UK; Blackwell: Malden, MA, USA, 2000.

25. Urry, J. Mobilities; Polity Press: Cambridge-Malden, MA, USA, 2007.

26. Giddens, A. Runaway World: How Globalization Is Reshaping Our Lives; Taylor \& Francis: Abingdon, UK, 2003.

27. Vertovec, S. Super-diversity and its implications. Ethn. Racial Stud. 2007, 30, 1024-1054. [CrossRef]

28. Ager, A.; Strang, A. Understanding Integration: A Conceptual Framework. J. Refug. Stud. 2008, $21,166-191$. [CrossRef]

29. Crul, M. Super-diversity vs. assimilation: How complex diversity in majority-minority cities challenges the assumptions of assimilation. J. Ethn. Migr. Stud. 2016, 42, 54-68. [CrossRef]

30. Badiou, A.; Lancelin, A. Pokhvala Politytsi (Éloge de la Politique); Repa, A., Ed.; Nika-Centre: Kyiv and Lviv, Ukraine, 2019.

31. Cottyn, I. Livelihood Trajectories in a Context of Repeated Displacement: Empirical Evidence from Rwanda. Sustainability 2018, 10, 3521. [CrossRef]

32. Kim, Y.Y. Theory Reflections: Cross-Cultural Adaptation Theory; Association of International educators NAFSA: Washington, DC, USA, 2008. Available online: https://www.nafsa.org/sites/default/files/ektron/files/ underscore/theory_connections_crosscultural.pdf (accessed on 2 May 2020).

33. The Concept of the National Program appointed to deal with the consequences of the Chornobyl NPP accident and social defense of the citizens for the period of 1994-1995, and till 2000; Resolution of Verkhovna Rada of Ukraine; \# 3422-XII; Verkhovna Rada of Ukraine: Kyiv, Ukraine, 1993. Available online: https://zakon.rada.gov.ua/laws/ show/3421-12 (accessed on 19 January 2020).

34. On the Legal Regime of the Territory Exposed to the Radioactive Contamination Resulting from the Chornobyl NPP Accident; Law of Ukraine No. 791a-XII; Verkhovna Rada of Ukraine: Kyiv, Ukraine, 2016. Available online: https://zakon.rada.gov.ua/laws/show/791\%D0\%B0-12 (accessed on 19 January 2020).

35. On the State Plan of Economic and Social Development of the Ukrainian SSR in 1987; Regulation of the Council of Ministers of the Ukrainian SSR \# 400; the Council of Ministers of the Ukrainian SSR: Kyiv, the Ukrainian SSR, 1986. Available online: https://zakon.rada.gov.ua/laws/show/400-86-\%D0\%BF/sp:max100 (accessed on 19 January 2020).

36. On Resettlement of the Citizens of Two Settlements of Polesskii Region of Kyiv Oblast and 12 Settlements of Narodychskii Region of Zhytomyr Oblast Exposed to the Radioactive Contamination Resulting from the Chornobyl NPP Accident; Regulation of the Council of Ministers of the Ukrainian SSR \# 224-r; the Council of Ministers of the Ukrainian SSR: Kyiv, the Ukrainian SSR, 1989. Available online: https://zakon.rada.gov.ua/laws/show/224-89-\%D1\%80 (accessed on 19 January 2020).

37. On Status and Social Defense of the Citizens Affected by the Chornobyl NPP Accident; Law of Ukraine \# 796-XII; Verkhovna Rada of Ukraine: Kyiv, Ukraine, 2019. Available online: https://zakon.rada.gov.ua/laws/show/ 796-12 (accessed on 19 January 2020). 
38. Ukraine. Recovery and Peacebuilding Assessment. Analysis of Crisis Impacts and Needs in Eastern Ukraine; Synthesis Report; EU: Brussels, Belgium; UN: New York, NY, USA; WBG: Washington, DC, USA, 2015; Volume 1, Available online: https://reliefweb.int/sites/reliefweb.int/files/resources/V1-RPA_Eng_rev2.pdf (accessed on 19 January 2020).

39. IOM's Assistance to Conflict-Affected People in Ukraine; Bi-Monthly Report; IOM/Ukraine: Kyiv, Ukraine, 2014. Available online: http://iom.org.ua/sites/default/files/iom_ukraine_idps_assistance_report_december_2014_4. pdf (accessed on 19 January 2020).

40. IOM's Assistance to Conflict-Affected People in Ukraine; Bi-Monthly Report; IOM/Ukraine: Kyiv, Ukraine, 2015. Available online: http://iom.org.ua/sites/default/files/iom_ukraine_idp_assistance_report_november_2015. pdf (accessed on 19 January 2020).

41. On Approval of the Concept of the Targeted State Program for Recovery and Peacebuilding in the Eastern Regions of Ukraine; Resolution of the Cabinet of Ministers of Ukraine, No. 892-r; the Cabinet of Ministers of Ukraine: Kyiv, Ukraine, 2016. Available online: https://zakon.rada.gov.ua/laws/show/892-2016-\%D1\%80 (accessed on 19 January 2020).

42. IOM's Assistance to Conflict-Affected People in Ukraine; Bi-Monthly Report; IOM/Ukraine: Kyiv, Ukraine, 2016. Available online: http://iom.org.ua/sites/default/files/iom_assistance_report_november_-december_2016_ english.pdf (accessed on 19 January 2020).

43. On Approval of the Strategy of Integration of Internally Displaced Persons and Implementation of Long-Term Solutions to Internal Displacement until 2020; Regulation of the Cabinet of Ministers of Ukraine, No. 909-r; the Cabinet of Ministers of Ukraine: Kyiv, Ukraine, 2017. Available online: https://zakon.rada.gov.ua/laws/show/9092017-\%D1\%80 (accessed on 19 January 2020).

44. IOM's Assistance to Conflict-Affected People in Ukraine; Bi-Monthly Report; IOM/Ukraine: Kyiv, Ukraine, 2018. Available online: http://iom.org.ua/sites/default/files/iom_ukraine_assistance_report_november-december_ 2018_eng.pdf (accessed on 19 January 2020).

45. IOM's Assistance to Conflict-Affected People in Ukraine; Bi-Monthly Report; IOM/Ukraine: Kyiv, Ukraine, 2019. Available online: http://iom.org.ua/sites/default/files/iom_ukraine_assistance_report_june-july_2019_eng.pdf (accessed on 19 January 2020).

46. IOM's Assistance to Conflict-Affected People in Ukraine; Bi-Monthly Report; IOM/Ukraine: Kyiv, Ukraine, 2019. Available online: http://iom.org.ua/sites/default/files/iom_ukraine_assistance_report_september_2019_eng. pdf (accessed on 19 January 2020).

47. IOM's Assistance to Conflict-Affected People in Ukraine; Bi-Monthly Report; IOM/Ukraine: Kyiv, Ukraine, 2019. Available online: http://iom.org.ua/sites/default/files/iom_ukraine_assistance_report_november-october_ 2019_eng.pdf (accessed on 19 January 2020).

48. National Monitoring System Report on the Situation of Internally Displaced Persons; Round 11; IOM: Kyiv, Ukraine, 2018. Available online: https://displacement.iom.int/system/tdf/reports/nms_round_11_eng_press.pdf?file= $1 \&$ type $=$ node $\& \mathrm{id}=4964$ (accessed on 19 January 2020).

49. National Monitoring System Report on the Situation of Internally Displaced Persons; Round 12; IOM: Kyiv, Ukraine, 2018. Available online: http://iom.org.ua/sites/default/files/nms_round_12_eng_screen.pdf (accessed on 19 January 2020).

50. National Monitoring System Report on the Situation of Internally Displaced Persons; Round 13; IOM: Kyiv, Ukraine, 2019. Available online: http://iom.org.ua/sites/default/files/nms_round_13_eng.pdf (accessed on 19 January 2020).

51. National Monitoring System Report on the Situation of Internally Displaced Persons; Round 14; IOM: Kyiv, Ukraine, 2019. Available online: http://iom.org.ua/sites/default/files/nms_round_14_eng_web.pdf (accessed on 19 January 2020).

52. Sabates-Wheeler, R. Mapping differential vulnerabilities and rights: 'opening' access to social protection for forcibly displaced populations. Comp. Migr. Stud. 2019, 7. [CrossRef]

53. Hendriks, M.; Burger, M.M. Unsuccessful Subjective Well-Being Assimilation among Immigrants: The Role of Faltering Perceptions of the Host Society. J. Happiness Stud. 2019, 1-22. [CrossRef]

54. Bradley, M. The Impact of Armed Conflict on Displacement; Technical Report; Institut Barcelona d'Estudis Internacionals: Barcelona, Spain, 2017.

55. Rajput, S.G. Internal Displacement and Conflict: The Kashmiri Pandits in Comparative Perspective; Routledge: Abington, UK, 2019. 
56. Smal, V. A Great Migration: What is the Fate of Ukraine's Internally Displaced Persons. A dataset on internally displaced persons from the Crimea and Donbass. Vox Ukraine. 2016. Available online: https://voxukraine.org/en/great-migration-how-many-internally-displaced-persons-are-there-inukraine-and-what-has-happened-to-them-en/ (accessed on 19 January 2020).

57. Mukomel, V. Migration of Ukrainians to Russia in 2014-2015. Discourses and Perceptions of the Local Population. In Migration and the Ukraine Crisis. A Two-Country Perspective; Pikulicka-Wilczewska, A., Uehling, G., Eds.; E-International Relations Publishing: Bristol, UK, 2017; pp. 105-115.

58. Dodonova, V.; Dodonov, R. Monologues on the Donbas. Selected Works on the Conflict in Eastern Ukraine; Vydavets Ruslan Khalikov: Kyiv, Ukraine, 2018.

59. The Attitudes of the Population of Ukraine towards IDPs; Press-Release on the Public-Opinion polls 2015-2018; Monitoring Results by the Institute of Sociology; National Academy of Sciences of Ukraine: Kiev, Ukraine, 2019. Available online: https://dif.org.ua/article/stavlennya-naselennya-ukraini-do-vnutrishnoperemishchenikh-osib (accessed on 19 January 2020).

60. Foreign Ministry Comment on Statements by Georgia and Ukraine Regarding the Anniversary of August 2008 Events. The official Site of the Ministry of Foreign Affairs of the Russian Federation. 12 August 2016. Available online: https://www.mid.ru/ru/foreign_policy/news/-/asset_publisher/cKNonkJE02Bw/content/id/2391051? p_p_id=101_INSTANCE_cKNonkJE02Bw\&_101_INSTANCE_cKNonkJE02Bw_languageId=en_GB (accessed on 19 January 2020).

61. General Assembly Adopts Text on Status of Georgia's Refugees, Internally Displaced Persons, Calls upon Participants in Geneva Discussions to Intensify Efforts. General Assembly Adopts Text on Status of Georgia's Refugees, Internally Displaced Persons, Calls upon Participants in Geneva Discussions to Intensify Efforts. General Assembly Plenary Seventy-third Session. In Proceedings of the 88th Meeting (PM) GA/12151, New York, NY, USA, 4 June 2019. Available online: https://www.un.org/press/en/2019/ga12151.doc.htm (accessed on 19 January 2020).

62. Roudik, P. Georgia; Russian Federation: Separatist Regions of Georgia Conclude Military Agreements with Russia; Library of Congress: Washington, DC, USA, 2010. Available online: https:/www.loc.gov/law/foreign-news/article/georgia-russian-federation-separatist-regions-ofgeorgia-conclude-military-agreements-with-russia/ (accessed on 19 January 2020).

63. A Heavy Burden-Internally Displaced in Georgia: Stories from Abkhazia and South Ossetia; Internal Displacement Monitoring Centre: Geneva, Switzerland, 2008. Available online: http://www.internal-displacement.org/sites/ default/files/publications/documents/2008-eu-georgia-heavy-burden-country-en\%20\%281\%29.pdf (accessed on 19 January 2020).

64. Georgia: IDPs in Georgia still need attention. A Profile of the Internal Displacement Situation; Internal Displacement Monitoring Centre: Geneva, Switzerland, 2009. Available online: https://reliefweb.int/report/ georgia/georgia-idps-georgia-still-need-attention (accessed on 19 January 2020).

65. Georgia: Partial Progress towards Durable Solutions for IDPs; Internal Displacement Monitoring Centre: Geneva, Switzerland, 2012. Available online: http://www.internal-displacement.org/sites/default/files/publications/ documents/georgia-overview-mar2012.pdf (accessed on 19 January 2020).

66. Guiding Principles on Internal Displacement; UN (OCHA): New York, NY, USA, 1998; (updated 2004). Available online: https://www.unhcr.org/protection/idps/43ce1cff2/guiding-principles-internal-displacement.html (accessed on 19 January 2020).

67. Special Abkhazia Issue: Ten Years after the War Report from Institute for War and Peace Reporting; IWPR: London, UK, 2002. Available online: https://reliefweb.int/report/georgia/special-abkhazia-issue-ten-years-after-war (accessed on 19 January 2020).

68. Law of the Republic of Abkhazia on Citizenship of the Republic of Abkhazia. 2005. Available online: http://www.emb-abkhazia.ru/konsulskie_voprosy/zakon_j/ (accessed on 19 January 2020).

69. Law of the Republic of South Ossetia on Amendment to the Treaty on Alliance and Integration between the Russian Federation and the Republic of South Ossetia. 2018. Available online: http://www.parliamentrso. org/node/2287 (accessed on 19 January 2020).

70. Law of the Republic of South Ossetia on Citizenship of the Republic of South Ossetia. 2008. Available online: http://www.parliamentrso.org/node/85 (accessed on 19 January 2020). 
71. On Some Issues of Social Benefits for Internally Displaced Persons; The CMU Resolution \# 365; the Cabinet of Ministers of Ukraine: Kyiv, Ukraine, 2019. Available online: https://zakon.rada.gov.ua/laws/show/365-2016$\%$ D0\%BF\#n33 (accessed on 19 January 2020).

72. Law of Ukraine on Provision Rights and Freedoms of Internally Displaced Persons. \# 1706-VII; the Cabinet of Ministers of Ukraine: Kyiv, Ukraine, 2020. Available online: https://zakon.rada.gov.ua/laws/show/1706-18 (accessed on 19 January 2020).

73. Background: Six-Point Peace Plan for the Georgia-Russia Conflict; Report; Deutsche Presse Agentur: Hamburg, Germany, 2008. Available online: https://reliefweb.int/report/georgia/background-six-point-peace-plangeorgia-russia-conflict (accessed on 19 January 2020).

74. Orzechowski, M. Conflicts in Donbass and the Kerch Strait as an Element of the Neo-Imperialist Expansion Strategy of the Russian Federation in the Post-Soviet Area. Ukr. Policymak. 2018, 3, 43-50. [CrossRef]

75. Presidential Decree on Recognizing of the Republic of Crimea Independence. \#147. 2014. Available online: http://kremlin.ru/acts/bank/38202 (accessed on 19 January 2020).

76. Presidential Decree on Recognizing of the Republic of South Ossetia Independence. \# 1261. 2008. Available online: http://kremlin.ru/acts/bank/27958 (accessed on 19 January 2020).

77. Presidential Decree on Recognizing of the Republic of Abkhazia Independence. 2008. \# 1260. 2008. Available online: http://kremlin.ru/acts/bank/27957 (accessed on 19 January 2020).

78. Treaty of Alliance and Strategic Partnership between the Russian Federation and Republic of Abkhazia. 2014. Available online: http://kremlin.ru/supplement/4783 (accessed on 19 January 2020).

79. Public Opinion Survey to Assess the Changes in Citizens' Awareness of Civil Society and Their Activities; USAID/Kyiv: Kyiv, Ukraine, 2018. Available online: https://dif.org.ua/uploads/pdf/3235987555af01ce0267550.88880763.pdf (accessed on 19 January 2020).

80. Public Opinion Survey to Assess the Changes in Citizens' Awareness of Civil Society and Their Activities; USAID/Kyiv: Kyiv, Ukraine, 2019. Available online: https://dif.org.ua/uploads/pdf/1820094705d9ccb76b43dc5.92039369.pdf (accessed on 19 January 2020).

81. 2017-2018 Main Changes. UN SCORE for Eastern Ukraine; UN Office in Ukraine: Kyiv, Ukraine, 2018. Available online: https://use.scoreforpeace.org/files/publication/pub_file//Trends2018_UA.pdf (accessed on 19 January 2020).

82. Bazaluk, O. The Problem of War and Peace: A Historical and Philosophical Analysis. Philos. Cosmol. 2017, 18, 85-103.

83. The CMU Resolution "Some Issues of Social Benefits for Internally Displaced Persons". \# 365; the Cabinet of Ministers of Ukraine: Kyiv, Ukraine, 2019. Available online: https://zakon.rada.gov.ua/laws/show/365-2016$\%$ D0\%BF\#n33 (accessed on 19 January 2020).

84. Haran, O.; Yakovlyev, M.; Zolkina, M. Identity, war, and peace: Public attitudes in the Ukraine-controlled Donbas. Eurasian Geogr. Econ. 2019, 60, 684-708. [CrossRef]

85. Balinchenko, S. Mythologeme-Related Crisis of Identity: Reality and Fictional Markers of Alienation. Future Hum. Image 2019, 11, 5-13. [CrossRef]

86. Sustainable Development Goals: Ukraine; National Baseline Report; Ministry of Economic Development and Trade of Ukraine: Kyiv, Ukraine, 2017. Available online: http://www.un.org.ua/images/sdgs_ nationalReportEN_Web.pdf (accessed on 3 May 2020).

(C) 2020 by the authors. Licensee MDPI, Basel, Switzerland. This article is an open access article distributed under the terms and conditions of the Creative Commons Attribution (CC BY) license (http://creativecommons.org/licenses/by/4.0/). 